\title{
Evaluation of free radical scavenging capacity of methoxy containing-hybrids of thiosemicarbazone-triazole and their influence on glucose transport
}

\author{
Ademola O. Ayeleso ${ }^{1,2}$, Jitcy S. Joseph ${ }^{3}$, Oluwafemi O. Oguntibeju ${ }^{4}$ and Emmanuel Mukwevho ${ }^{1 *}$
}

\begin{abstract}
Background: Diabetes mellitus is a metabolic disease in which the body is unable to produce insulin or respond to insulin production, consequently leading to abnormal metabolism of carbohydrates, lipids and proteins causing elevation of glucose in the blood. Oxidative stress, an imbalance between the production of free radicals and body antioxidant system has been implicated in the pathogenesis of diabetes. Free radicals attack important macromolecules leading to cell damage. Antioxidants are intimately involved in the prevention of damage caused by free radicals
\end{abstract}

Methods: The anti-diabetic effects of hybrid compounds (2a-h) of thiosemicarbazone and triazole containing methoxy groups at C (4) positions were tested against genes involved in glucose metabolism (Glut-4, Mef2a and Nrf-1) using quantitative real time PCR (qPCR). Free radical scavenging capacity (FRAP, TEAC, DPPH and ORAC) of the hybrids was also carried out by using established antioxidant capacity assays.

Results: From the results, hybrid compounds $2 \mathrm{~b}$ and $2 \mathrm{~h}$ showed more pronounced effects in up-regulating diabetes associated genes which are important in the up-regulation of glucose uptake. All the hybrid compounds also showed free radical scavenging abilities.

Conclusion: In conclusion, hybrid compounds ( $2 \mathrm{~b}$ and $2 \mathrm{~h}$ ) can be useful as potential drugs for the management of diabetes mellitus.

Keywords: Hybrid compound, Thiosemicarbazone, Triazole, Free radical, Diabetes

\section{Background}

Thiosemicarbazones are biologically active compounds which are obtained by the condensation of thiosemicarbazide or a substituted thiosemicarbazide with a suitable aldehyde or ketone. Thiosemicarbazones derivatives have been reported to have antidiabetic, antiviral, anticancer, antibacterial, antifungal, and antimalarial effects [1-8]. 1,2,3-Triazole is a heterocyclic compound which belong to a class of azole. A triazole is a five-membered aromatic ring which contains at least one nitrogen atom and another heteroatom such as nitrogen, oxygen, or sulphur in

\footnotetext{
* Correspondence: emmanuel.mukwevho@nwu.ac.za

${ }^{1}$ Department of Biochemistry, North-West University, Mmabatho 2735, South Africa

Full list of author information is available at the end of the article
}

the ring. Triazole derivatives are known to have antifungal, antibacterial, anticancer, antimalaria, anti-inflammatory activities [9-14]. Derivatives of triazole have also been reported to protect pancreatic $\beta$ cells against endoplasmmic reticulum stress-mediated dysfunction and death [15]. Hybrid compounds of thiosemicarbozone and triazole have been evaluated for their biological activities against malaria, obesity and diabetes [16-18].

A free radical is any molecular species that is capable of independent existence, possessing an unpaired electron in an atomic orbital [19]. Examples of free radicals include superoxide $(\mathrm{O} 2 \bullet-)$, hydroxyl $(\mathrm{OH} \bullet)$, peroxyl (RO2•), hydroperoxyl (HO2•), alkoxyl (RO•), peroxyl (ROO•), nitric oxide (NO•), nitrogen dioxide (NO2•) and lipid peroxyl (LOO•) [20]. Antioxidants are 
molecules which can safely interact with free radicals and terminate the chain reaction before vital molecules are damaged, inhibiting the oxidation of susceptible biomolecules such as proteins, lipids and DNA [21] thus, playing a role in the prevention of oxidative damage to the body. Antioxidants are known to exhibit antioxidant activity by donation of hydrogen atoms or single-electron transfer to a radical [22].

Type 2 diabetes mellitus is a disease where the body either produces little insulin / ceases to produce insulin, or becomes progressively resistant to its action [23]. Upon stimulation by insulin, GLUT4 is a glucose transporter that is responsible for the uptake of glucose molecules into muscle cells and adipose tissue and it is reported to be indirectly regulated by NRF-1 through transcription of the gene myocyte enhancer factor 2 (MEF2) [18, 24, 25]. MEF2 is a transcription factor that binds to the promoter of the GLUT4 gene which in turn, regulates its transcription and expression [25, 26]. Experimental analysis on the antidiabetic and antioxidant potentials had earlier been done on hybrids compounds from thiosemcarbazone and triazole [18]. These compounds were further improved through the addition of a functional group (aromatic ring containing methoxy) at C (4) position (Fig. 1). The aim of this study was therefore to investigate antioxidant potentials i.e. free radical scavenging ability of the improved synthesized hybrid compounds of thiosemcarbazone and triazole as well as their influence on the expression of some genes associated with type 2 diabetes.

\section{Methods}

\section{Synthesis of hybrid compounds}

The synthesis of the hybrid compounds (2b-h) were synthesized in a similar fashion as published by $[17,18]$ except for the addition of an electron donating group (methoxy substituent to $\mathrm{C}(4)$ position of the aromatic ring joining thiosemicarbazone and triazole..

\section{Collection of cell lines}

3T3-L1 adipocytes cell lines used in this study were collected from Prof E.O. Ojuka at the Department of Human Biology, University of Cape Town, South Africa. The cell lines were originally from American Type Culture Collection (ATCC) through Prof J.O. Holloszy at the Washington University School of Medicine, Missouri, USA.

\section{Cell culture and treatments}

3T3-L1 adipocytes cell lines were cultured using Dulbecco's modified Eagles medium (DMEM) (GIBCO, USA) supplemented with 10\% Foetal calf serum (BioWest, France) and $1 \%$ penicillin/streptomycin/fungizone (GIBCO, USA) at $37{ }^{\circ} \mathrm{C}$ with $5 \% \mathrm{CO} 2$ and $95 \%$ humidity. The maintenance of the cells was done in continuous passage by trypsinization of subconfluent cultures with Trypsin/Versene (Highveld, RSA). Differentiation was induced by introduction of medium containing $2 \%$ Foetal calf serum and $2 \%$ penicillin/ streptomycin/fungizone when pre-adipocytes were $80 \%$ confluent. Cells were kept in this medium for 5 days until adipocytes were well formed. Differentiated 3T3-L1 pre-adipocytes were treated with $5 \mu \mathrm{L}$ of compounds $(10 \mathrm{mg} / \mathrm{mL}) 2 \mathrm{~b}-\mathrm{h}$ or $100 \mathrm{nM}$ insulin or Metformin for $4 \mathrm{~h}$.

\section{Quantitative real-time PCR}

Total RNA was isolated and purified from the treated cells using QIAzol lysis reagent (QIAGEN Sciences, USA) and RNA clean and Concentrator-25 (Inqaba Biotech, SA). Double stranded cDNA was synthesized from $3 \mu \mathrm{g}$ of the total RNA using Superscript Reverse Transcriptase III (Invitrogen, USA). Real time quantitative

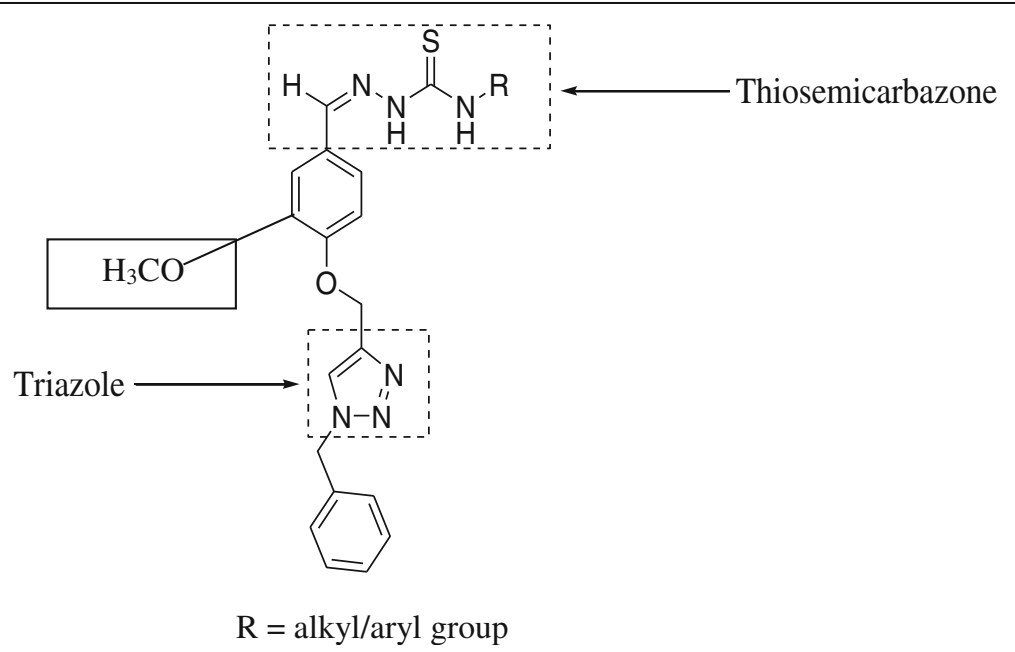

Fig. 1 General chemical structure of the thiosemicarbazone- triazole hybrid compound with methoxy aromatic linker 
PCR was done in triplicate using Rotor gene-3000 quantitative real-time PCR machine using Sensi Mix SYBR No-ROX One-Step Kit (Bioline, UK). The primers used were mouse Glut4 gene (Forward primer- 5' GCA GCG AGT GAC TGG AAC A 3'; Reverse primer- 5'CCA GCC ACG TTG CAT TGT AG 3'), Nrf-1 gene (Forward primer- 5' AAA CAC AAA CTC AGG CCA CC 3'; Reverse primer-5' CCA TCA GCC ACA GCA GAG CA 3') and $M e f 2 a$ gene (Forward primer-5' GTG TAC TCA GCA ATG CCG AC 3'; and Reverse primer-5' AAC CCT GAG ATA ACT GCC CTC 3'). The amplification occurred in a 3-step cycle: denaturation at $95{ }^{\circ} \mathrm{C}$ for $5 \mathrm{~s}$, annealing at $60{ }^{\circ} \mathrm{C}$ for $10 \mathrm{~s}$, and extension at $72{ }^{\circ} \mathrm{C}$ for $15 \mathrm{~s}$. Relative mRNA expression was normalised to mouse Actin reference gene (Forward primer- 5' GAG ACC TTC AAC ACC CCA GCC 3'; Reverse primer- 5' GGA GAG CAT AGC CCT CGT AG 3') and calculated according to relative standard method.

\section{ABTS radical scavenging activity}

This assay was carried out using the principle of 2,2azino-bis (3-ethylbenzothiazoline-6 sulphonic acid) (ABTS) radical scavenging activity according to [27]. ABTS+ solution was prepared and left overnight before use by mixing ABTS salt $(8 \mathrm{mM})$ with potassium persulfate $(3 \mathrm{mM})$ and then storing the solution in the dark until the assay could be performed and $\mathrm{ABTS}^{+}$ solution was then diluted with distilled water. The

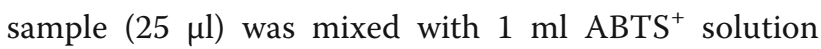
$(300 \mu \mathrm{l})$ and left for $30 \mathrm{~min}$ at room temperature. The sample was read at a wavelength of $734 \mathrm{~nm}$. Trolox was used as the standard and results were expressed as $\mu \mathrm{mol} \mathrm{TE} / \mathrm{g}$ sample. All determinations were done in triplicates.

\section{Ferric reducing antioxidant power (FRAP) assay}

The FRAP assay was done using the method described by [28]. The sample $(10 \mu \mathrm{l})$ was mixed with $300 \mu \mathrm{l}$ FRAP reagent (a mixture of acetate buffer $\left(\mathrm{pH}\right.$ 3.6), tripyridyl triazine (TPTZ) and $\mathrm{FeCl}_{3} \cdot 6 \mathrm{H}_{2} \mathrm{O}$ ). After incubation at room temperature for $30 \mathrm{~min}$, the samples were read at a wavelength of $593 \mathrm{~nm}$. Ascorbic acid was used as the standard and the results were expressed as $\mu \mathrm{mol} \mathrm{AAE} / \mathrm{g}$ sample. All determinations were done in triplicates.

\section{DPPH free radical scavenging activity}

DPPH free radical scavenging activity of the sample was carried out according to a modified method of [29]. The sample $(10 \mu \mathrm{l})$ was reacted with DPPH solution $(190 \mu \mathrm{l})$ and the absorbance was determined after $30 \mathrm{~min}$ at a wavelength of $517 \mathrm{~nm}$. Free radical scavenging activity of the samples was expressed according to the equation below:
Percent (\%) inhibition of DPPH activity

$$
\frac{A^{o}-A}{A^{o}} \times 100
$$

Where $A^{\circ}$ is the absorbance of DPPH. in solution without an antioxidant and $A$ is the absorbance of $\mathrm{DPPH}$. in the presence of an antioxidant.

\section{Oxygen radical absorbance capacity (ORAC) assay}

The ORAC assay was carried out according to the method of [30] using a fluorescence plate reader (Thermo Fisher Scientific, Waltham, Mass., USA). The reaction consisted of $12 \mu \mathrm{l}$ of diluted aqueous plant extracts and 138ul of fluorescein $(14 \mu \mathrm{M})$, which was used as a target for free radical attack. The reaction was initiated by the addition of $50 \mu \mathrm{l} \mathrm{AAPH}(768 \mu \mathrm{M})$ and the fluorescence (emission $538 \mathrm{~nm}$, excitation $485 \mathrm{~nm}$ ) recorded every $1 \mathrm{~min}$ for $2 \mathrm{~h}$ in triplicates. Trolox was used as the standard and results expressed as $\mu \mathrm{mol} \mathrm{TE} / \mathrm{g}$ sample.

\section{Statistical analysis}

Results are presented as means \pm SD. Statistical analysis was performed by one-way ANOVA followed by the Tukey's post hoc test. The level of significance was accepted at $P<0.05$. All statistical analyses were performed using GraphPad InStat 3 software.

\section{Results}

Free radical scavenging abilities of the hybrids

The results in Fig. 2 showed that all the hybrid compounds possess hydrogen or electron donating abilities through ABTS assay in relation trolox as standard with hybrid compound $\mathbf{2 b}$ showing the highest TEAC value of $312.9 \pm 1.41 \mu \mathrm{mol} \mathrm{TE} / \mathrm{g}$. Other hybrid compounds had TEAC values of $294.6 \pm 1.10 \mu \mathrm{mol} \mathrm{TE} / \mathrm{g}$ (2c), $229.8 \pm$ $1.21 \mu \mathrm{mol} \mathrm{TE} / \mathrm{g}$ (2d), $246.7 \pm 0.40 \mu \mathrm{mol} \mathrm{TE} / \mathrm{g}$ (2e), 227.1 $\pm 2.55 \mu \mathrm{mol} \mathrm{TE} / \mathrm{g}(\mathbf{2 f}), 268.9 \pm 2.09 \mu \mathrm{mol} \mathrm{TE} / \mathrm{g}(\mathbf{2 f})$ and $157.4 \pm 0.64 \mu \mathrm{mol} \mathrm{TE} / \mathrm{g}(\mathbf{2 h})$. The results in Fig. 3 showed the strength of the reducing power of the hybrid compounds with $\mathbf{2 c}, \mathbf{2 d}$ and $\mathbf{2 g}$ having FRAP values of $19.2 \pm 2.37 \mu \mathrm{mol} \mathrm{AAE} / \mathrm{g}, 21.81 \pm 2.06 \mu \mathrm{mol} \mathrm{AAE} / \mathrm{g}, 20.62$ $2.09 \mu \mathrm{mol} \mathrm{AAE} / \mathrm{g}$ respectively, followed by $\mathbf{2 b}, \mathbf{2 e}, \mathbf{2 f}$ and $\mathbf{2 h}$ with FRAP values of $12.9 \pm 0.25 \mu \mathrm{mol} \mathrm{AAE} / \mathrm{g}$, $12.2 \pm 0.21 \mu \mathrm{mol} \mathrm{AAE} / \mathrm{g}, 11.25 \pm 1.23 \mu \mathrm{mol} \mathrm{AAE} / \mathrm{g}$ and $12.9 \pm 0.76 \mu \mathrm{mol} \mathrm{AAE} / \mathrm{g}$ respectively. Among the hybrid compounds, $\mathbf{2 b}$ had the most pronounced inhibition of DPPH $(68.9 \% \pm 1.40)$ while others have $26.1 \% \pm 0.69$ (2c), $21.1 \% \pm 1.59 \quad(\mathbf{2 d}), \quad 26.0 \% \pm 0.29 \quad$ (2e), $32.4 \pm 0.37$ (2f), $28.5 \% \pm 2.12(\mathbf{2 g}), 22.0 \% \pm 0.69$ (2 h) inhibition of DPPH (Fig. 4). All the hybrid compounds showed inhibition of peroxyl radical with $\mathbf{2 c}, \mathbf{2 d}, \mathbf{2 f}$ and $\mathbf{2 g}$ having ORAC values of $270.9 \pm 2.12 \mu \mathrm{mol}$ TE/g., $190.2 \pm$ 


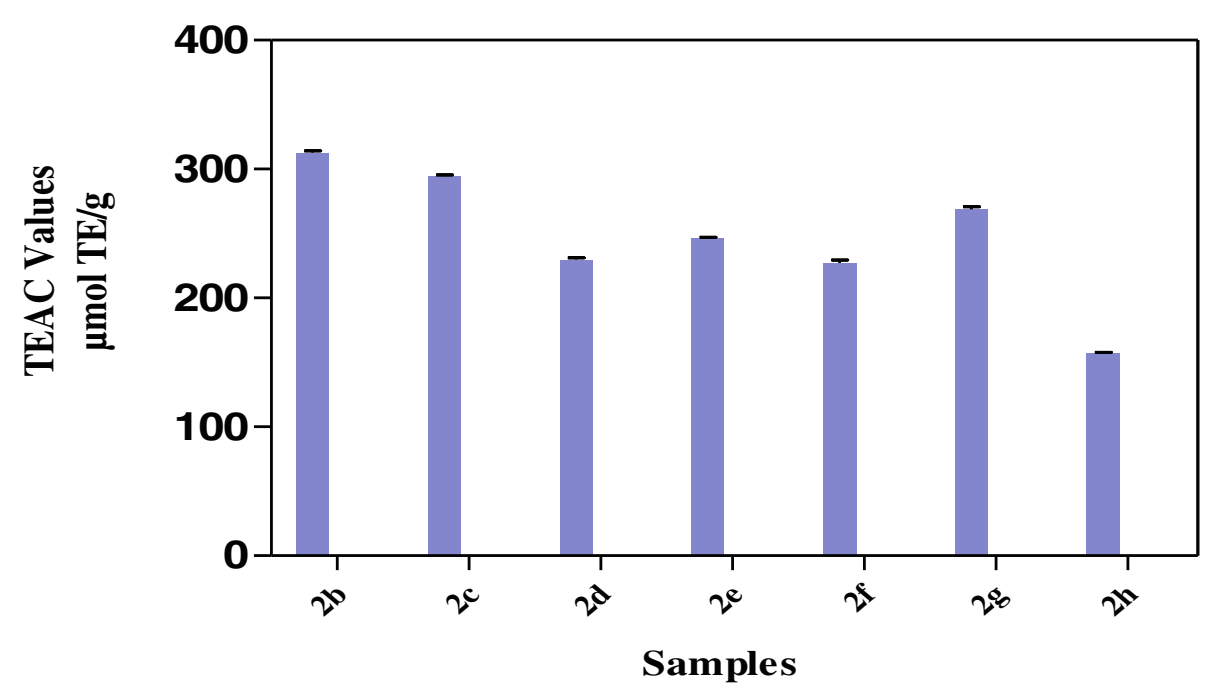

Fig. 2 ABTS radical scavenging activity of the hybrid compounds

$4.92 \mu \mathrm{mol} \mathrm{TE} / \mathrm{g} ., 268.3 \pm 1.29 \mu \mathrm{mol} \mathrm{TE} / \mathrm{g}$ and $227.9 \pm$ $1.59 \mu \mathrm{mol} \mathrm{TE} / \mathrm{g}$ respectively followed by $\mathbf{2 b}, \mathbf{2 e}$, and $\mathbf{2 h}$ with ORAC values of $53.0 \pm 5.11 \mu \mathrm{mol} \mathrm{TE} / \mathrm{g}, 38.84 \pm$ $7.31 \mu \mathrm{mol} \mathrm{TE} / \mathrm{g}$ and $61.4 \pm 2.00 \mu \mathrm{mol} \mathrm{TE} / \mathrm{g}$ respectively (Fig. 5).

\section{Glut-4 gene expression in response to treatment with the} hybrids

The results in Fig. 6 showed that all the hybrid compounds except 2 f stimulated the expression of glut-4 better than control. Hybrid compounds $2 \mathbf{b}, \mathbf{2 d}, \mathbf{2 e}, \mathbf{2 g}$ and $2 \mathbf{h}$ showed expression of glut-4 better than the standard drugs, insulin and metformin when compared with the control. Hybrid compound $2 \mathbf{h}$ showed a more pronounced increase ( 3.9 fold of the control) and was followed by hybrid compounds $\mathbf{2 b}, \mathbf{2 d}$ and $\mathbf{2 g}$ with 3.3, 3.6 and 3.3 folds increase respectively when compared with the control.

Mef2a gene expression in response to treatment with the hybrids

The results in Fig. 7 showed that the hybrid compounds 2b, 2c, 2d, 2f and 2 h expressed Mef $2 a$ better than standard drugs, insulin and metformin relative to the control. The effect of $\mathbf{2} \mathbf{b}$ was almost 12 fold increase in the expression of Mef $2 a$ followed by hybrid compounds $\mathbf{2 d}$ and $\mathbf{2 h}$ which exhibited 6.3 and 7.4 folds increase, respectively relative to the control.

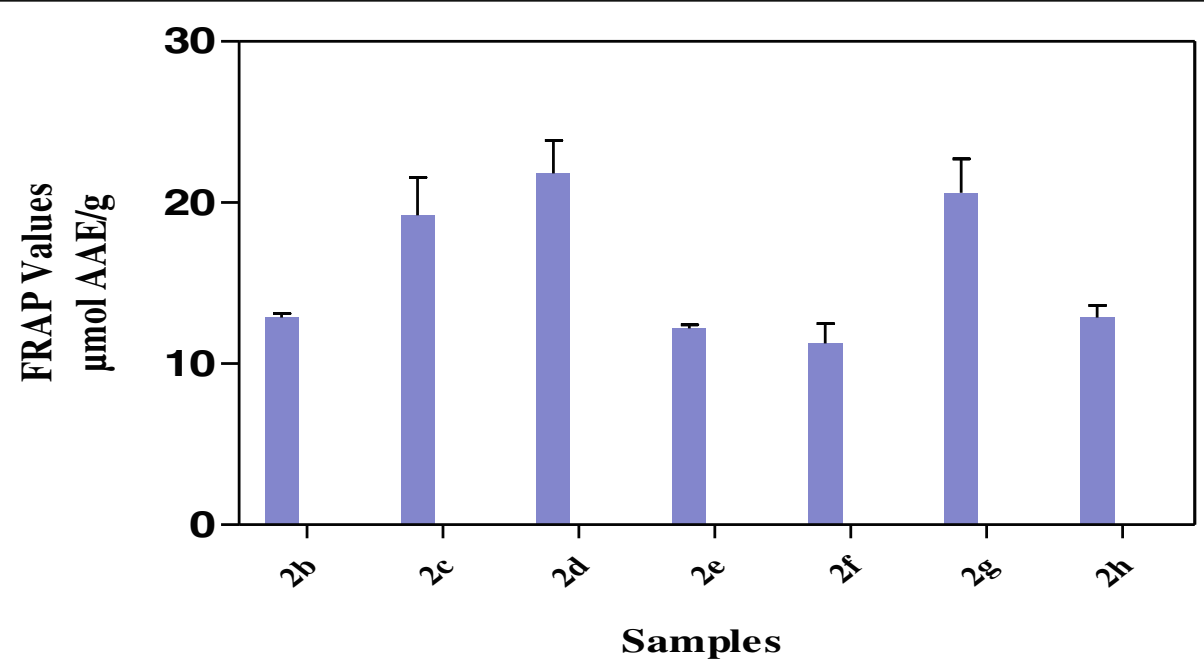

Fig. 3 Ferric reducing antioxidant power of the hybrid compounds 


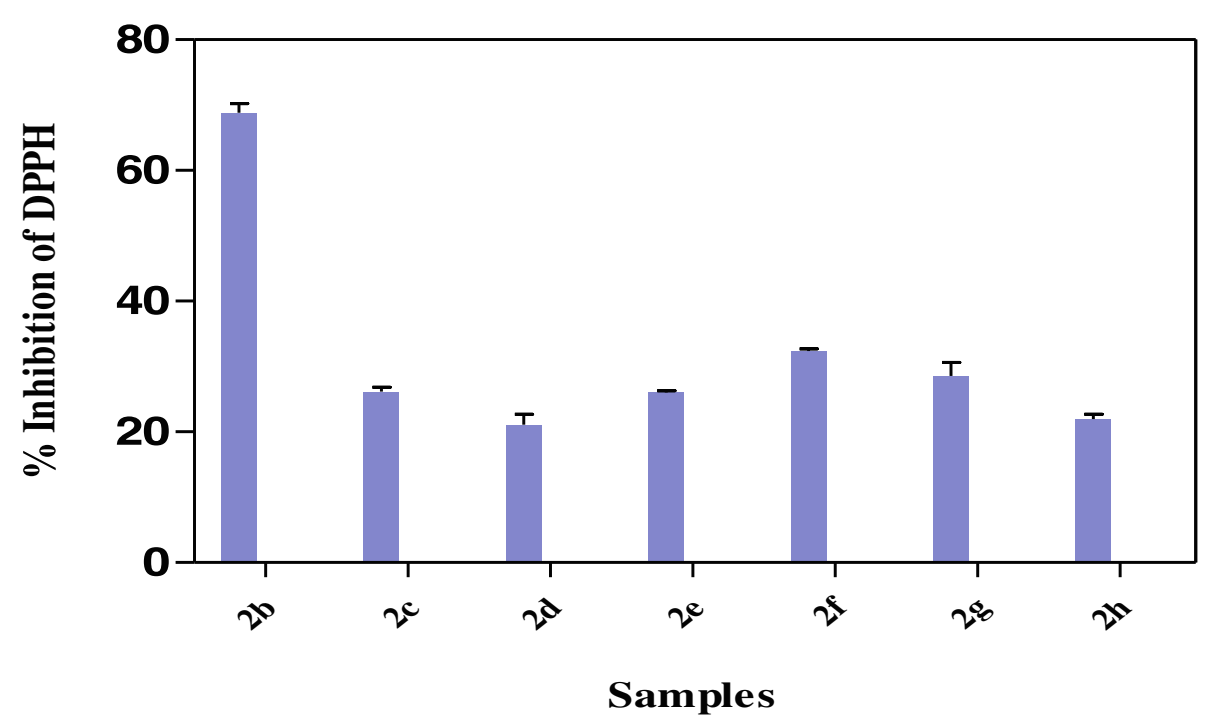

Fig. 4 DPPH radical scavenging activity of the hybrid compounds

Nrf-1 gene expression in response to treatment with the hybrids

The result in Fig. 8 showed that all the hybrid compounds except $\mathbf{2 e}$ and $\mathbf{2 f}$ stimulated the expression on Nrf-1 gene in relative to the control. Hybrid compounds $\mathbf{2 b}, \mathbf{2 c}, \mathbf{2}$ g and $\mathbf{2 h}$ expressed $N r f-1$ better than standard drugs, insulin and metformin. Hybrid compound $\mathbf{2 h}$ showed a more pronounced increase in expression (4.8 fold of the control) while $\mathbf{2 b}, \mathbf{2 c}$ and $\mathbf{2 g}$ showed 3.8, 3.4 and 3 folds increase in the expression of $N r f-1$ gene relative to the control.

\section{Discussion}

Antioxidants prevent cell and tissue damage as they act as free radical scavengers, neutralizing the electrical charges on free radicals and thereby hinders them from accepting electrons from other molecules [31, 32]. Elevated levels of free radical molecules result in oxidative stress in cells, leading to the destruction of vital macromolecules including DNA, lipids, and proteins [33]. Oxidative stress, an imbalance between the production of free radicals and the ability of the body antioxidant system to fight back, has been implicated in the pathogenesis of many chronic diseases including diabetes mellitus. Antioxidants alleviate oxidative stress, the adverse effects of free radical [34] and reportedly help in slowing down aging process and fight diseases such as diabetes mellitus, hypertension and cancer [32, 35].

Hybrid compounds, $\mathbf{2 b}, \mathbf{2 d}$ and $\mathbf{2 c}$ are non-polar long alkyl chains of the amine moiety while non-polar short alkyl chains of the amine moiety are hybrids, $2 \mathrm{a}, 2 \mathrm{e}$ and 2f (Table 1). Hybrids compounds, $\mathbf{2 g}$ and $\mathbf{2 h}$ are aryl

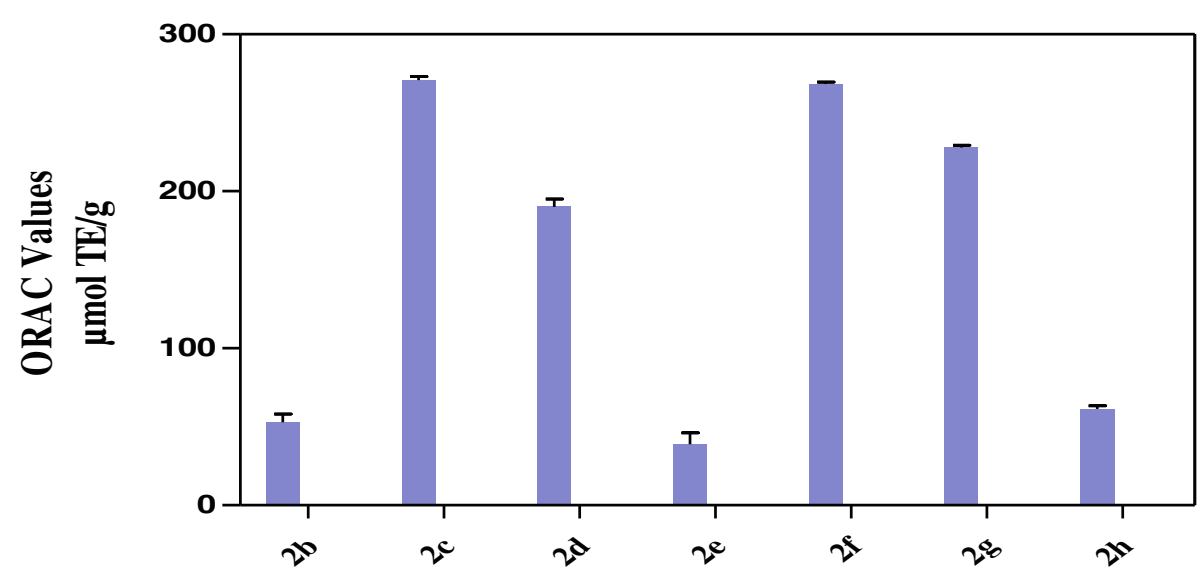

Samples

Fig. 5 Oxygen radical absorbance capacity of the hybrid compounds 


\section{Glut 4}

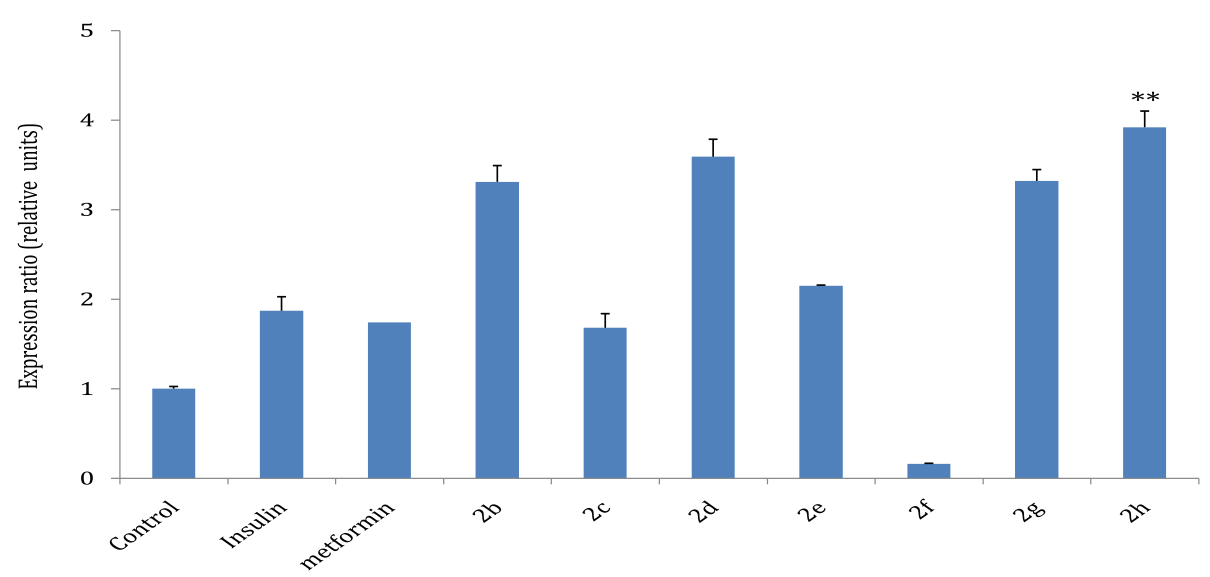

Fig. 6 Glut-4 expression in response to treatment with hybrids 2b-h. Results are presented as means \pm SD. Level of significance was accepted at $P<0.05$. The $P$ value, control vs $2 \mathrm{~h} P<0.01\left(^{* *}\right)$, Insulin vs $2 \mathrm{~h} P<0.01$ (*) $^{*}$

containing amine groups (Table 1). In this study, the biological activities of hybrids (2b-h), containing electron donating group (methoxy group) at the aromatic linker of both thiosemicarbazone and triazole at $\mathrm{C} 4$ position were investigated for their free radical scavenging abilities and expression of genes involved in glucose uptake. ABTS assay is an excellent means for determining the antioxidant activity of hydrogen-donating and chain-breaking antioxidants [36]. It involves electron transfer process and is based on discolorations of ABTS by antioxidant compounds thus reflecting the amount of ABTS radicals that are scavenged within a fixed time period in relation to that of trolox [37]. In this study, ABTS scavenging ability reported as trolox equivalence antioxidant capacity (TEAC) revealed that the hybrid compound $\mathbf{2 b}$ had the highest value which was followed by $2 \mathbf{c}$ while $\mathbf{2 h}$ had the lowest (Fig. 2).

The FRAP assay is reproducible and linearly related to the molar concentration of the antioxidant [38] and the reducing capacity of a compound could be used as an important indicator of its possible antioxidant activity [39]. In reducing power assay, antioxidants act as electron donor which reduces the $\mathrm{Fe}^{3+}$ complex to its $\mathrm{Fe}^{2+}$ and the reducing power is indicated by higher absorbance values [34]. In this study, assay of reducing activity was based on the reduction of ferric to the ferrous form in the presence of reductants (antioxidants) in the tested hybrid compounds and measuring the greater absorbance of blue colour solution at $700 \mathrm{~nm}$ showed greater reducing power. The values for the reducing

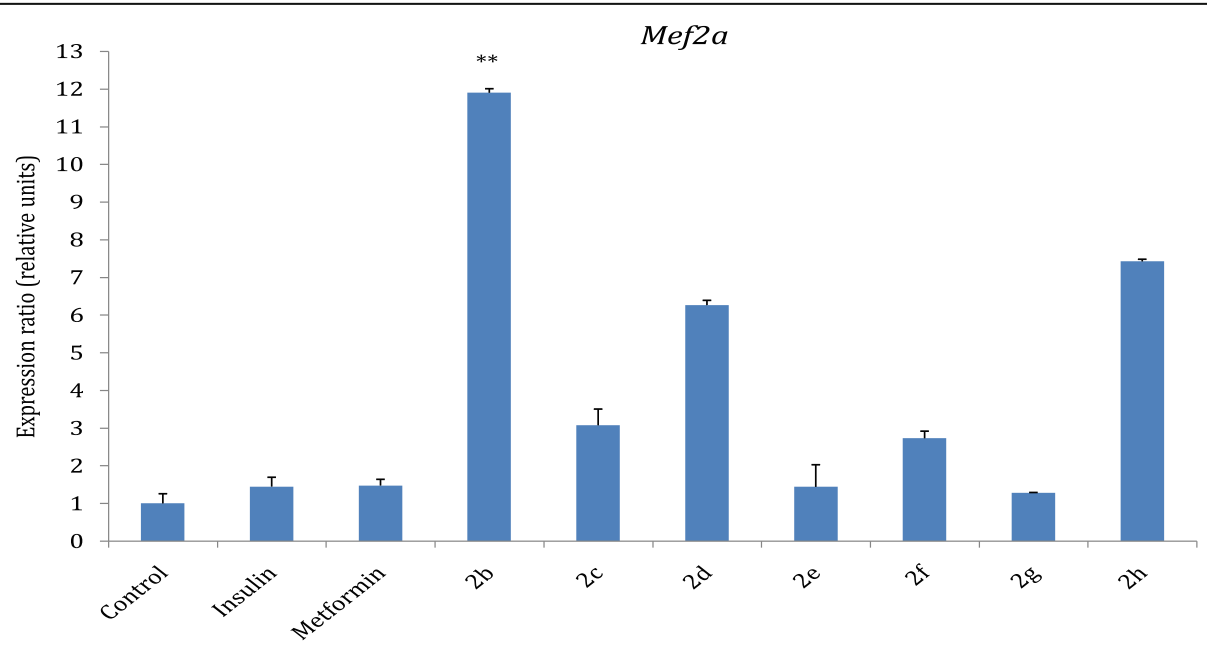

Fig. 7 Mef2a expression in response to treatment with hybrids $2 b-h$. Results are presented as means \pm SD. Level of significance was accepted at $P<0.05$. The $P$ value, control vs $2 \mathrm{~b} P<0.01(* *)$, Insulin vs $2 \mathrm{~b} P<0.01(* *)$ 


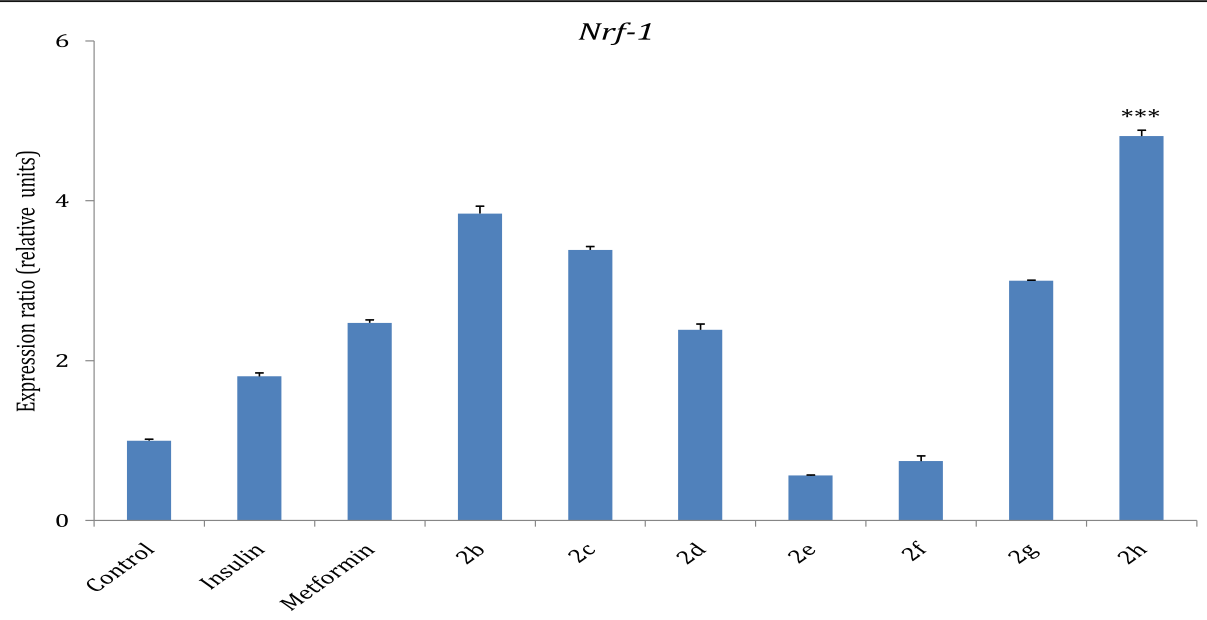

Fig. $8 \mathrm{Nrf}-1$ expression in response to treatment with hybrids $2 \mathrm{~b}-\mathrm{h}$. Results are presented as means $\pm \mathrm{SD}$. Level of significance was accepted

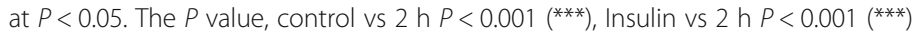

power (from $\mathrm{Fe}^{3+}$ to $\mathrm{Fe}^{2+}$ ) of the hybrid compounds was reported as ascorbic acid equivalents (Fig. 3) with $\mathbf{2 d}$ having highest FRAP value, followed by $2 \mathbf{g}$ while $2 \mathbf{f}$ was the lowest. The results indicated that all the hybrid compounds had reducing properties, thus revealed their antioxidative potentials.

In this study, DPPH inhibition value shows the antioxidant ability of the hybrid compounds by accepting an electron or hydrogen radical to become a stable diamagnetic molecule. DPPH assay has been widely used as quick, reliable, and reproducible parameter for showing in vitro antioxidant activity reducing the violet colour to yellow coloured product in the presence of antioxidant [34]. DPPH• is a stable radical showing a maximum absorbance at $515 \mathrm{~nm}$ and method is based on the reduction of $\mathrm{DPPH}$ - in alcoholic solution in the presence of a hydrogen-donating antioxidant due to the formation of the non-radical form $\mathrm{DPPH}-\mathrm{H}$ in the reaction [40]. The study showed that the highest DPPH inhibition value was $\mathbf{2 c}$ and followed by $2 \mathbf{f}$ while the 2d was the lowest (Fig. 4). The results confirmed that the hybrids were able to reduce the stable radical DPPH to the yellow-colored diphenylpicrylhydrazone suggesting their scavenging potentials by its proton donating ability.

The ORAC assay uses 2,2-azobis(2-amidinopropane) dihydrochloride (AAPH) for free radical generation and measures the antioxidant inhibition of peroxyl-radical-induced oxidations which shows the radical chain breaking antioxidant activity by $\mathrm{H}$ atom transfer [41]. All the hybrid compounds showed ORAC values 2c having the highest with 2f as the next while the lowest value was 2e (Fig. 5). The results also confirm the antioxidant potency of the hybrid compounds.
GLUT4 is a glucose transporter that is responsible for the uptake of glucose molecules into muscle cells and adipose tissue upon stimulation by insulin [25]. The expression of Glut4 in relation to the test compounds was compared with the control. As shown in Fig. 6, all the hybrid compounds except 2 f showed more expression of Glut4 than the control with hybrid compounds 2b, 2d, 2e, 2g, and $2 \mathrm{~h}$ stimulating Glut4 expression more than insulin and metformin.

Furthermore, $M e f 2 a$ gene expression was investigated on compound $\mathbf{2 b - h}$. (Fig. 7). MEF2 is a transcription factor that binds to the promoter of the GLUT4 gene thereby regulating its transcription and expression. Ramachandran et al [24] has also shown that the transcription of the gene myocyte enhancer factor 2 (MEF2) is regulated by NRF-1. Mef $2 a$ was better expressed by 2b, 2c, 2d, 2f, $2 \mathbf{h}$ than the standard drugs, insulin and metformin relative to the control.

In addition, Hybrids $\mathbf{2 b}$-h $\mathbf{h}$ were also tested for their effect on the expression of $\mathrm{Nrf-1}$ gene (Fig. 8). The test results showed that all the hybrids except $2 \mathbf{e}$ and $\mathbf{2 f}$ stimulated the expression of $N r f-1$ gene relative to the control (Fig. 8), with hybrids $\mathbf{2 b}, \mathbf{2 c}, \mathbf{2 g}$, and $\mathbf{2 h}$ expressing $N r f-1$ better than insulin and metformin relative to the control. Overall, hybrid $\mathbf{2 b}$ with a non-polar short alkyl chain of the amine moiety and $\mathbf{2 h}$, an aryl containing amine group were consistently up-regulating Glut-4, Mef2a and Nrf-1.

\section{Conclusion}

The study showed the abilities of the hybrid compounds in trapping free radicals which are present in biological systems from a wide variety of sources. This study also revealed that hybrids $\mathbf{2 b}$ and $\mathbf{2 h}$ had consistent stimulatory effects on glucose uptake as 
Table 1 Synthesized thiosemicarbazone-triazole hybrid compounds ( $\mathrm{R}=$ alkyl/aryl group)

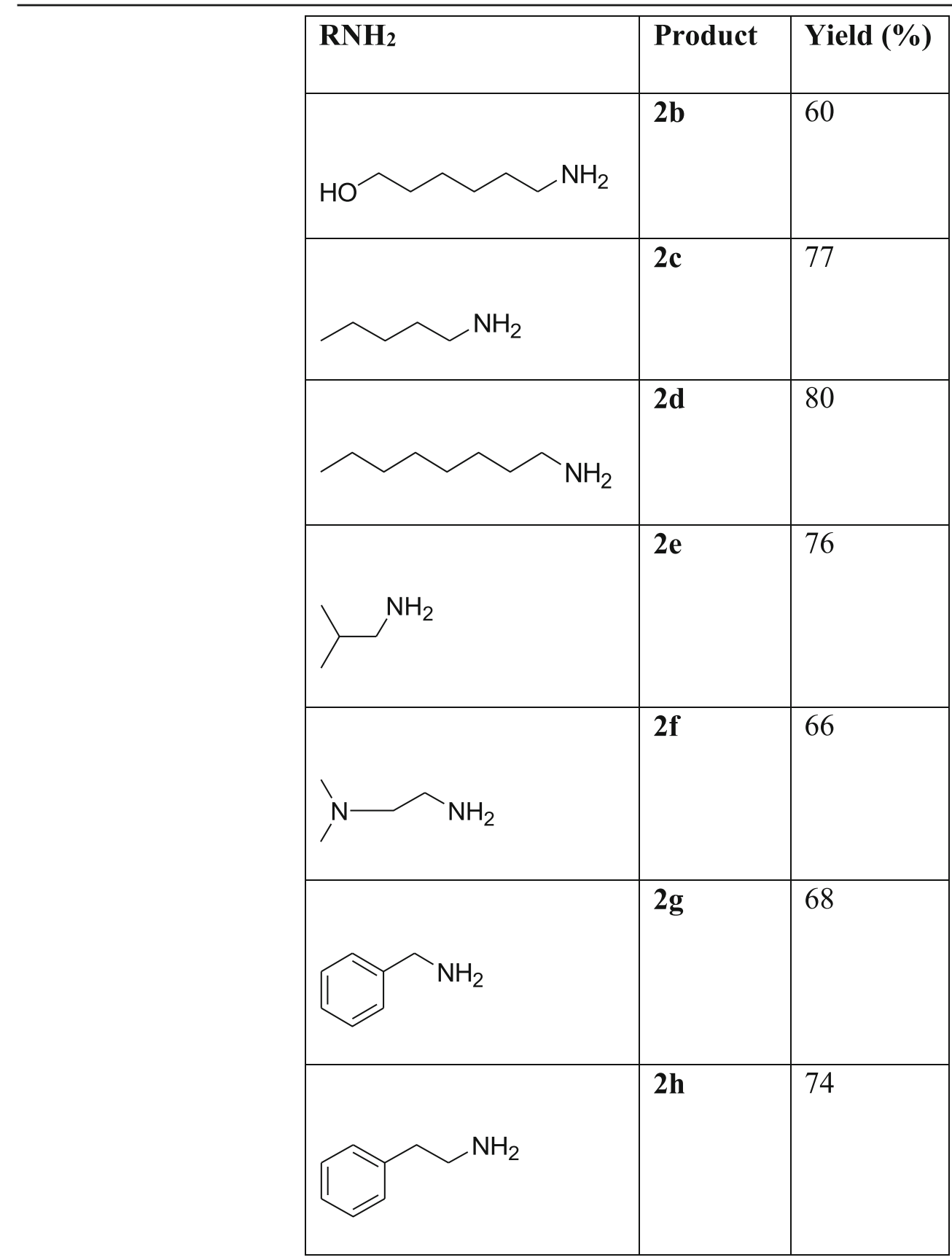

shown on the expression of Glut-4, Mef2a and Nrf-1. These compounds might be important in the upregulation of glucose uptake. It can be deduced from the results that the hybrids could help in the scavenging of free radicals and thus inhibit the oxidative mechanisms that could lead to diabetic complications. Hence, this study shows that these compounds can be useful as therapeutic agents in the treatment of diabetes mellitus.

\section{Abbreviations}

AAE: Ascorbic Acid Equivalent; ABTS: 2,2- azino-bis (3-ethylbenzothiazoline-6 sulphonic acid); ATCC: American Type Culture Collection; DPPH: 2,2-diphenyl1-picrylhydrazyl; FRAP: Ferric Reducing Antioxidant Power; Glut-4: Glucose transporter 4; Mef2a: Myocyte enhancing factor 2A; Nrf-1: Nuclear respiratory factor-1; ORAC: Oxygen Radical Absorbance Capacity; qPCR: Quantitative real time PCR; TE: Trolox Equivalent

\section{Acknowledgements}

We thank the National Research Foundation of South Africa (NRF), North-West University, South Africa and Cape Peninsula University of 
Technology, South Africa and Adeleke University, Nigeria for support. We also thank the Department of Chemistry, University of Johannesburg, South Africa for the synthesis of the compounds.

\section{Funding}

National Research Foundation of South Africa (NRF) provided funding for the study to Prof Emmanuel Mukwevho (Grant numbers: 76194, 88062 and 109326). Cape Peninsula University of Technology, South Africa also provided funding through Prof Oluwafemi Oguntibeju (reference no: CPUTRJ23).

\section{Availability of data and materials}

The datasets supporting the conclusions of this article are included within the article.

\section{Authors' contributions}

$\mathrm{EM}, \mathrm{OO}, \mathrm{AOA}$ and JSJ designed the experiments, $\mathrm{AOA}$ and JSJ carried out the experiments and analysed the results, AOA and JSJ wrote the manuscript, EM and $\mathrm{OO}$ supervised the experiments. All authors read and approved the final manuscript.

\section{Ethics approval and consent to participate}

Not applicable.

\section{Consent for publication}

Not applicable.

\section{Competing interests}

The authors declare that there are no competing interests.

\section{Publisher's Note}

Springer Nature remains neutral with regard to jurisdictional claims in published maps and institutional affiliations.

\section{Author details}

'Department of Biochemistry, North-West University, Mmabatho 2735, South Africa. ${ }^{2}$ Department of Biochemistry, Adeleke University, Ede, Osun State P.M.B. 250, Nigeria. ${ }^{3}$ Department of Life \& Consumer Sciences, University of South Africa, Florida Campus, Johannesburg 1709, South Africa. ${ }^{4}$ Oxidative Stress Research Centre, Department of Biomedical Sciences, Cape Peninsula University of Technology, Bellville 7535, South Africa.

Received: 28 July 2018 Accepted: 1 November 2018

Published online: 06 December 2018

\section{References}

1. Shipman C Jr, Smith SH, Drach JC, Klayman DL. Thiosemicarbazones of 2acetylpyridine, 2-acetylquinoline, 1-acetylisoquinoline, and related compounds as inhibitors of herpes simplex virus in vitro and in a cutaneous herpes Guinea pig model. Antivir Res. 1986;6:197-222. https://doi.org/10. 1016/0166-3542(86)90002-1.

2. Usman A, Razak LA, Chantrapromma S, Fun HK, Sreekanth A, Sivakumar S, Kurup MRP. Bis[1-(pyridin-2-yl)ethanone-kN 4-phenylthiosemicarbazonatoK2N4,S] manganese(II). Acta Crystallogr C. 2002;58:461-3. https://doi.org/10. 1016/j.poly.2005.12.023

3. Philip V, Suni V, Maliyeckal R, Kurup P, Nethaji M. Copper(II) complexes derived from di-2-pyridyl ketone $N(4), N(4)$-(butane-1,4diyl)thiosemicarbazone: Crystal structure and spectral studies. Polyhedron. 2006;25:1931-8

4. Kizilcikli I, Kurt YD, Akkurt B, Genel AY, Birteksöz S, Otük G, Ulküseven B. Antimicrobial activity of a series of thiosemicarbazones and their $Z \mathrm{n}^{\prime \prime}$ and Pd" complexes. Folia Microbiol (Praha). 2007;52:15-25. https://doi.org/10. 1007/BF02932132.

5. Dilović I, Rubcić M, Vrdoljak V, Kraljević Pavelić S, Kralj M, Piantanida I, Cindrić M. Novel thiosemicarbazone derivatives as potential antitumo agents: synthesis, physicochemical and structural properties, DNA interactions and antiproliferative activity. Bioorg Med Chem. 2008;16:518998. https://doi.org/10.1016/j.bmc.2008.03.006

6. Khan SA, Yusuf M. Synthesis, spectral studies and in vitro antibacterial activity of steroidal thiosemicarbazone and their palladium (Pd (II)) complexes. Eur J Med Chem. 2009;44:2270-4. https://doi.org/10.1016/j. ejmech.2008.06.008.
7. Glisoni RJ, Chiappetta DA, Moglioni AG, Sosnik A. Novel 1-indanone thiosemicarbazone antiviral candidates: aqueous solubilization and physical stabilization by means of cyclodextrins. Pharm Res. 2011;29:739-55.

8. Kadowaki S, Munekane M, Kitamura Y, Hiromura M, Kamino S, Yoshikawa Y, Saji H, Enomoto S. Development of new zinc dithiosemicarbazone complex for use as oral antidiabetic agent. Biol Trace Elem Res. 2013;154:111-9. https://doi.org/10.1007/s12011-013-9704-x.

9. Berger O, Kaniti A, van Ba CT, Vial H, Ward SA, Biagini GA, Bray PG, O'Neill PM. Synthesis and antimalarial activities of a diverse set of triazolecontaining furamidine analogues. ChemMedChem. 2011;6:2094-108. https://doi.org/10.1002/cmdc.201100265.

10. Banday $A H$, Shameem SA, Ganai BA. Antimicrobial studies of unsymmetrical bis- 1,2,3-triazoles. Org Med Chem Lett. 2012;2:13. https://doi.org/10.1186/ 2191-2858-2-13

11. Pattan SR, Gadhave P, Tambe V, Dengale S, Thakur D. Synthesis and evaluation of some novel 1,2,4-triazole derivatives for antmicrobial, antitubercular and anti- inflammatory activities. Indian J Chem. 2012;51B: 297-301 ISSN: 0975-0983.

12. Zou Y, Zhao Q, Liao J, Hua H, Yu S, Chai X, Xu M, Wua Q. New triazole derivatives as antifungal agents: synthesis via click reaction, in vitro evaluation and molecular docking studies. Bioorg Med Chem Lett. 2012;22: 2959. https://doi.org/10.1016/j.bmcl.2012.02.042.

13. Bekircan O, Kahveci B, Kucuk M. Synthesis and anticancer evaluation of some new unsymmetrical 3,5- diaryl-4h-1,2,4-triazole derivatives. Turk J Chem. 2006;30:29-40.

14. Pokhodylo N, Shyyka O, Matiychuk V. Synthesis of 1,2,3-triazole derivatives and evaluation of their anticancer activity. Sci Pharm. 2013;81:663-76. https://doi.org/10.3797/scipharm.1302-04.

15. Duan H, Arora D, Li Y, Setiadi H, Xu D, Lim HY, Wang W. Identification of 1,2,3- triazole derivatives that protect pancreatic $\beta$ cells against endoplasmmic reticulum stress-mediated dysfunction and death through the inhibition of C/EBP-homologous protein expression. Bioorg Med Chem. 2016;24:2621-30. https://doi.org/10.1016/j.bmc.2016.03.057.

16. Kinfe HH, Belay $\mathrm{YH}$. Synthesis and biological evaluation of novel thiosemicarbazone- triazole hybrid compounds antimalarial agents. S Afr J Chem. 2013:66:130-5.

17. Kinfe HH, Belay $\mathrm{YH}$, Joseph JS, Mukwevho E. Evaluation of the influence of thiosemicarbazone-triazole hybrids on genes implicated in lipid oxidation and accumulation as potential anti-obesity agents. Bioorg Med Chem Lett. 2013;23:5275-8. https://doi.org/10.1016/j.bmcl.2013.08.028.

18. Ayeleso AO, Joseph JS, Belay YH, Mazibuko SE, Kinfe H, Oguntibeju O, Mukwevho E. Novel hybrid compounds from thiosemicarbazone and triazole as antidiabetic agents and their antioxidant potentials. Biomed Res. 2017;28:411-20 ISSN: 0970-938X.

19. Lobo V, Patil A, Phatak A, Chandra N. Free radicals, antioxidants and functional foods: impact on human health. Pharmacogn Rev. 2010;4:118-26. https://doi.org/10.4103/0973-7847.70902.

20. Dilis $V$, Trichopoulou A. Assessment of antioxidants in foods and biological samples: a short critique. Int J Food Sci Nutr. 2010;61:441-8. https://doi.org/ 10.3109/09637480903386234

21. Sen S, Chakraborty R, Sridhar C, Reddy YSR, De B. Free radicals, antioxidants, diseases and phytomedicines: current status and future prospect. International Journal of Pharmaceutical Sciences Review and Research. 2010; 3:91-100 ISSN 0976- 044X

22. Quideau S, Deffieux D, Douat-Casassus C, Pouységu L. Plant polyphenols: chemical properties, biological activities, and synthesis. Angew Chem Int Ed. 2011;50:586-621. https://doi.org/10.1002/anie.201000044.

23. Chakraborty R, Rajagopala R. Diabetes and insulin resistance associated disorders-disease and the therapy. Curr Sci. 2002;83:1533-8.

24. Ramachandran B, Yu G, Gulick T. Nuclear respiratory factor 1 controls myocyte enhancer factor 2A to provide a mechanism for coordinate expression of respiratory chain subunits. J Biol Chem. 2008;283:11935-46. https://doi.org/10.1074/jbc.M707389200.

25. Ferreira Z, Ayeleso A, Mukwevho E. Control of carbohydrate and lipid metabolism by NRF-1 and sirtuins: implications on type 2 diabetes and obesity. Chemical Biology Letters. 2014;1:66-76 ISSN 2347-9825.

26. Michael LF, Wu Z, Cheatham RB, Puigserver P, Adelmant G, Lehman JJ, Kelly DP, Spiegelman BM. Restoration of insulin-sensitive glucose transporter (GLUT4) gene expression in muscle cells by the transcriptional coactivator PGC-1. Proc Natl Acad Sci U S A. 2001:98:3820-5. https://doi.org/10.1073/ pnas.061035098. 
27. Re R, Pellegrini N, Proteggente A, Pannala A, Yang M, Rice-Evans C. Antioxidant activity applying an improved ABTS radical cation decolorization assay. Free Radic Biol Med. 1999;26:1231-7.

28. Benzie IFF, Strain JJ. The ferric reducing ability of plasma (FRAP) as a measure of antioxidant power: the FRAP assay. Anal Biochem. 1996;239:70-6.

29. Zheleva-Dimitrova DZ. Antioxidant and acetylcholinesterase inhibition properties of Amorpha fruticosa L. and Phytolacca americana L. Pharmacogn Mag. 2013;9:109-13. https://doi.org/10.4103/0973-1296.111251.

30. Ou B, Hampsch-Woodill M, Prior RL. Development and validation of an improved oxygen radical absorbance capacity assay using fluorescein as the fluorescent probe. J Agric Food Chem. 2001;49:4619-26. https://doi.org/10. 1021/j010586o

31. Oboh G, JBT R. Antioxidants in foods: A new challenge for food processors leading edge antioxidants research. New York US: Nova Science Publishers Inc; 2007. p. 35-64.

32. Oboh G, Ademosun AO, Ademiluyi AO, Omojokun OS, Nwanna EE, Longe KO. In vitro studies on the antioxidant property and inhibition of amylase, -glucosidase, and agiotensin 1-converting enzyme by polyphenol-rich extracts from cocoa (Theobroma cacao) bean. Patholog Res Int. 2014;2014:549287: 6 pages. https://doi.org/10.1155/2014/549287.

33. Nemudzivhadi V, Masoko P. In vitro assessment of cytotoxicity, antioxidant, and anti-inflammatory activities of Ricinus communis (Euphorbiaceae) leaf extracts. Evid Based Complement Alternat Med. 2014;2014:625961: 8 pages. https://doi.org/10.1155/2014/625961.

34. Kumar S, Kumar R, Dwivedi A, Pandey AK. In vitro antioxidant, antibacterial, and cytotoxic activity and in vivo effect of Syngonium podophyllum and Eichhornia crassipes leaf extracts on isoniazid induced oxidative stress and hepatic markers. Biomed Res Int. 2014;2014:459452, 11 pages. https://doi. org/10.1155/2014/459452.

35. Liu RH. Health benefits of fruit and vegetables are from additive and synergistic combinations of phytochemicals. Am J Clin Nutr. 2003;78:517S-20S.

36. Sudha G, Priya MS, Shree Rl, Vadivukkarasi S. In vitro free radical scavenging activity of raw pepino fruit (Solanum muricatum aiton). Int I Curr Pharm Res. 2011:3:0975-7066

37. Osawa T, Kavakishi S, Namiki M, Kuroda Y, Shankal DM, Waters MD. Antimutagenesis and Anticarcinogenesis mechanisms II. New York, NY, USA: Plenum; 1990

38. Ahmad J, Khan I. Antioxidant potential of Abutilon indicum (L.) Sw. Journal of plant pathology and. Microbiology. 2012;3:124. https://doi.org/10.4172/ 2157-7471.1000124.

39. Hazra B, Biswas S, Mandal N. Antioxidant and free radical scavenging activity of Spondias pinnata. BMC Complement Altern Med. 2008;8:63-75. https://doi.org/10.1186/1472-6882-8-63.

40. Singh S, Das SS, Singh G, Schuff C, de Lampasona MP, Catalán CA. Composition, invitro antioxidant and antimicrobial activities of essential oil and oleoresins obtained from black cumin seeds (Nigella sativa L). Biomed Res Int. 2014:2014:918209: 10 pages. https://doi.org/10.1155/2014/918209.

41. Ayeleso AO, Oguntibeju OO, Brooks NL. Invitro study on the antioxidant potentials of the leaves and fruits of Nauclea latifolia. Scientific World Journal. 2014;2014:437081: 8 pages. https://doi.org/10.1155/2014/437081.

Ready to submit your research? Choose BMC and benefit from:

- fast, convenient online submission

- thorough peer review by experienced researchers in your field

- rapid publication on acceptance

- support for research data, including large and complex data types

- gold Open Access which fosters wider collaboration and increased citations

- maximum visibility for your research: over $100 \mathrm{M}$ website views per year

At $\mathrm{BMC}$, research is always in progress.

Learn more biomedcentral.com/submissions 